\title{
Antioxidants in yacon products and effect of long term storage
}

\author{
Antioxidantes em produtos de yacon e efeito de armazenamento a longo prazo
}

\author{
Alejandra CASTRO ${ }^{1,2 *}$, Maciel CABALLERO ${ }^{1}$, Adelina HERBAS $^{1}$, Sergio CARBALLO ${ }^{1}$
}

\begin{abstract}
Yacon (Smallanthus sonchifolius (Poepp. and Endl.) H. Robinson) is a storage root originally grown in the Andean highlands. The fresh roots are perishable and quickly turn brown during handling and processing. Aiming to prolong shelf-life and to preserve the antioxidant compounds in yacon roots, $3 \mathrm{~mm}$ thick yacon slices were dried in a drying cabinet at 40,50 , and $60{ }^{\circ} \mathrm{C}$ to a moisture content of $10-14 \%$, and yacon strips were sun dried to a moisture content of 15-20\%. The total phenolic content was measured by the Folin-Ciocalteu method, and the quenching capacity was evaluated by measuring the amount of DPPH (1,1-diphenyl-2-pidrylhydrazyl) inhibited in samples after drying and after 7 months of storage. The results showed that it is possible to preserve the antioxidant capacity in yacon after cabinet or sun drying. Both yacon chips and strips presented total phenolic content values similar to those of fresh yacon roots. Both products also showed a high inhibition capacity of DPPH (1,1-diphenyl-2-pidrylhydrazyl). A significant decrease in the phenolic content was observed in the yacon chips after storage, which indicates that the sun dried strips are more suitable for storage.
\end{abstract}

Keywords: yacon; phenolic content; drying; storage; antioxidant capacity.

\begin{abstract}
Resumo
Yacon (Smallanthus sonchifolius (Poepp. e Endl.) H. Robinson) é uma cultura de raiz de reserva, originária dos planaltos andinos. As raízes frescas são perecíveis e escurecem facilmente durante o manuseio e o processamento. Com o objetivo de aumentar o tempo de prateleira e a preservação de antioxidantes nas raízes frescas, rodelas finas (chips) de raízes de $3 \mathrm{~mm}$ de tamanho foram secas numa estufa a 40 , 50 e $60^{\circ} \mathrm{C}$ e pedaços de raízes também foram secas ao sol até apresentarem umidade de $10-14 \%$ e 15-20\%, respectivamente. O conteúdo de fenóis totais foi determinado pelo método de Folin-Ciocalteu, e a estabilidade oxidativa foi avaliada através da determinação da quantidade de DPPH (1,1-diphenyl-2-pidrylhydrazyl) inibida nas amostras após a secagem e durante os 7 meses de armazenamento. Os resultados mostram que a secagem das raízes na estufa e ao sol permitiu manter a capacidade antioxidante das raízes de yacon. Ambos os produtos de secagem apresentaram teor de compostos fenólicos similares ao das raízes frescas e elevada inibição de 1,1-diphenyl-2-pidrylhydrazyl. Foi observada uma redução significativa do teor de fenóis em chips após o armazenamento o que indica que os pedaços secos ao sol são mais adequados para o armazenamento.
\end{abstract}

Palavras-chave: yacon; compostos fenólicos; secagem; armazenamento; capacidade antioxidante.

\section{Introduction}

Yacon (Smallanthus sonchifolius (Poepp. and Endl.) H. Robinson) is a storage root originally grown in the Andean highlands covering regions from Ecuador, Peru, Bolivia, and northwestern Argentina (GRAU; REA, 1997). Fresh yacon roots are highly perishable and tend to quickly brown during post-harvest handling and processing. One option to prolong shelf-life of yacon roots is to process them into juice, syrup, or dehydrated products such as chips and strips (SEMINARIO; VALDERRAMA; MANRIQUE, 2003). During dehydration, enzymatic activity can be inhibited by heating and addition of inhibitors. However, dehydration can cause changes in the nutritional and organoleptic properties. The drying processes have to be well defined and optimized in order to retain as much as possible the nutritional properties.

The main cause for browning in vegetables is the presence of polyphenol oxidases, which have been extensively studied and also found in yacon roots (MAYER, 1986; QUEIROZ et al., 2008; YORUK; MARSHALL, 2003; YOSHIDA et al., 2002). Neves and Da Silva (2007) studied the properties of polyphenol oxidases from yacon roots as well as its inactivation and response to inhibitors. The authors concluded that they are relatively stable at $60-70{ }^{\circ} \mathrm{C}$ and are progressively inactivated as the temperature reaches 80 and $90^{\circ} \mathrm{C}$.

The phenolic content in yacon roots has been also investigated. Yan et al. (1999) found that yacon roots contain two major antioxidant compounds, identified as chlorogenic acid and tryptophan (48.5 and $14.6 \mu \mathrm{g} . \mathrm{g}^{-1}$, respectively; values on a fresh weight basis). Five caffeic acid derivates isolated from yacon roots have being identified: chlorogenic acid, 3,5-dicaffeoylquinic acid; 2,4- or 3,5-dicaffeoylaltraric acid; 2,5-dicaffeoylaltraric acid; and 2,3,5- or 2,4,5-tricaffeoylaltraric acid (SIMONOVSKA et al., 2003; TAKENAKA et al., 2003). It

\footnotetext{
Received 14/6/2011

Accepted 17/2/2012 (005338)

Center for Food and Natural Products, Faculty of Science and Technology, San Simon University, Calle Sucre frente parque La Torre, Cochabamba, Bolivia,

e-mail: alejandra.castro@food.lth.se

2 Division of Food Technology, Faculty of Engineering LTH, Lund University, PO Box 124, 22100 Lund, Sweden

${ }^{*}$ Corresponding author
} 
is equally important and necessary to determine the amount of phenols that remain after processing. The aim of the present study was to evaluate the effects of drying and storage on the retention of antioxidant capacity in yacon chips and strips.

\section{Materials and methods}

Fresh yacon roots were purchased from a local market. The samples came from Locotal, in the province of Chapare (Cochabamba, Bolivia). Roots were stored at room temperature until processing. Anhydrous sodium carbonate and gallic acid were obtained from Riedel-de-Haën (Seelze, Germany). Folin-Ciocalteu reagent and 1,1-diphenyl-2-pidrylhydrazyl (DPPH) were obtained from Sigma-Aldrich (St. Louis, MO). The Total Antioxidant Status kit (TAS) was obtained from Randox Laboratories (Crumlin, UK). Ethanol was obtained from Industrias La Bélgica (Santa Cruz, Bolivia).

Yacon roots were washed in running tap water, peeled manually while being immersed in distilled water, and cut into $3 \mathrm{~mm}$ thick slices using an industrial cutter (Metalúrgica SKYMSEN, Brazil). The chips were immersed in a lemon juice and distilled water solution, $\mathrm{pH} 3$, for 10 minutes Finally, the chips were dried at 40,50 , and $60^{\circ} \mathrm{C}$ in a drying cabinet (Binder - FD 53, Tuttlingen, Germany) to a moisture content of $10-14 \%$. Antioxidant capacity was measured in the fresh dried chips. The chips were then stored at room temperature in polyethylene bags for 7 months for further antioxidant capacity analysis. The same procedure described above was followed for the dried strips, with the exception that the roots were cut into $3 \mathrm{~cm}$ thick longitudinal pieces, placed on trays, and dried in a solar dryer for 5 days or until final moisture content about $15-20 \%$.

Approximately $300 \mathrm{~g}$ of dried chips or strips were ground in a knife mill (Retsh, Haan, Germany). A total of $500 \mathrm{mg}$ of ground sample was transferred into $125 \mathrm{~mL}$ flasks, and $20 \mathrm{~mL}$ of extraction solvent (1:1 v/v ethanol:water) was added. The extraction was carried out for 2 hours at $30^{\circ} \mathrm{C}$ in a shaker incubator (Innova 4080, Edison, USA). Finally, the extracts were filtered and diluted with the extraction solvent to $25 \mathrm{~mL}$.

Total phenolic content was determined using the Folin-Ciocalteu method (SINGLETON; ROSSI, 1965), with the following modification: $3.16 \mathrm{~mL}$ of water and $200 \mu \mathrm{L}$ of Folin-Ciocalteu reagent were added to $40 \mu \mathrm{L}$ of extract. After one minute, $600 \mu \mathrm{L}$ of a 1.9 mol.L $\mathrm{L}^{-1} \mathrm{Na}_{2} \mathrm{CO}_{3}$ (saturated solution) were added and mixed. Absorbance was measured at $765 \mathrm{~nm}$ after 2 hours using a spectrophotometer (Unicam, Leeds, UK). Results were expressed as mg of gallic acid equivalents GAE. $\mathrm{g}^{-1}$ of sample.

The DPPH assay is based on the determination of scavenging free 1,1-diphenyl-2-pidrylhydrazyl (DPPH) radicals (MOLYNEUX, 2004; PRIOR; WU; SCHAICH, 2005). A DPPH solution was prepared with $2.5 \mathrm{mg}$ of DPPH in $50 \mathrm{~mL}$ of ethanol. A blank was prepared mixing $1 \mathrm{~mL}$ of extraction solvent with $1 \mathrm{~mL}$ of DPPH solution. For sample analysis, $1 \mathrm{~mL}$ of the sample extract was mixed with $1 \mathrm{~mL}$ of DPPH. The reactions were allowed to proceed for 30 minutes at $20^{\circ} \mathrm{C}$ in the dark. The absorbance of the blank $\left(\mathrm{A}_{0}\right)$ and the sample extract $\left(\mathrm{A}_{\mathrm{s}}\right)$ were measured at $523 \mathrm{~nm}$.
The results were expressed in terms of percentage of DPPH reduction. $Q$, referrers to inhibition or quenching and is defined by the following Equation 1:

$Q=\frac{A_{0}-A_{s}}{A_{0}} \times 100$

Total antioxidant status (TAS) was measured with a kit from Randox Laboratories (Crumlin, UK) following the instructions of manufacturer. The method is based on the 2,2'-azino-bis(3-ethylbenzthiazoline-6-sulphonic acid) assay (ABTS assay) (PRIOR et al., 2005). The results were expressed in mmol trolox equivalents. $L^{-1}$.

All analyses were carried out in duplicate if not stated otherwise. Arithmetic mean values and standards derivations are shown for all measurements. Analysis of variance (ANOVA) was used for statistical analysis using Minitab (version 14, Minitab Inc. USA). Significant differences between means were evaluated using $t$-test. The level of significance was set at $\mathrm{p}<0.05$.

\section{Results and discussion}

The content of phenolic compounds in yacon chips and strips after drying was in the range of 6.8 to $10.1 \mathrm{mg} \mathrm{GAE} \cdot \mathrm{g}^{-1}$ with significant lower values for chips dried at 40 and $60{ }^{\circ} \mathrm{C}$. Similar behaviour was found when the percentage of DPPH quenched was determined. Chips dried at 40 and $60^{\circ} \mathrm{C}$ inhibited $75 \%$ of DPPH, whereas chips dried at $50^{\circ} \mathrm{C}$ and strips inhibited 88 and $80 \%$ of DPPH, respectively (Table 1). The slight difference in antioxidant activity between strips and chips dried at $50{ }^{\circ} \mathrm{C}$ is due to differences in the drying conditions. The strips were submitted to long-term exposure to oxidative conditions during drying. Phenolic compounds could have been oxidised by phenol oxidases.

Compared to other known natural sources of antioxidants that have been studied, such as tomato (Lycopersicon esculentum Mill) (CHANG et al., 2006), the content of total phenolic compounds is higher for yacon products, while the capacity of quenching DPPH is higher for tomato. Vasco, Ruales and Kamal-Eldin (2008) classified seventeen different crops from Ecuador based on analyses of total phenolic compounds. According to Vasco's classification, yacon strips and chips belong to the group of "crops with high phenolic content". The total phenolic values obtained for yacon strips and chips are higher than those determined in plums

Table 1. Total phenolic content (mg GAE. $\mathrm{g}^{-1}$, wet basis) and percentage of quenching of DPPH (Q\%) in yacon chips and strips after drying.

\begin{tabular}{ccc}
\hline Sample & $\begin{array}{c}\text { Total phenolic content } \\
\left(\mathrm{mg} \mathrm{GAE} \cdot \mathrm{g}^{-1}\right)\end{array}$ & $\begin{array}{c}\mathrm{Q}(\%) \\
(\text { quenching of DPPH })\end{array}$ \\
\hline Strips & $9.7 \pm 0.2^{\mathrm{a}}$ & $79.7 \pm 0.1^{\mathrm{b}}$ \\
Chips & & \\
$40^{\circ} \mathrm{C}$ & $7.1 \pm 0.1^{\mathrm{b}}$ & $75.4 \pm 0.3^{\mathrm{c}}$ \\
$50^{\circ} \mathrm{C}$ & $10.1 \pm 0.1^{\mathrm{a}}$ & $88.1 \pm 0.6^{\mathrm{a}}$ \\
$60^{\circ} \mathrm{C}$ & $6.8 \pm 0.1^{\mathrm{b}}$ & $74.6 \pm 0.1^{\mathrm{c}}$ \\
\hline
\end{tabular}

Values with different letter in the same column are significantly different $(\mathrm{p}<0.05)$. Mean values \pm standard deviation. 
(Prunus salicina Lindl.), strawberry (Fragaria ananassa Duch.) and tomato (Lycopersicon esculentum Mill.)

Furthermore, our results are similar to those reported by Lachman et al. (2007) with regard to the phenolic content. Lachman et al. (2007) determined the total phenolic content in fresh yacon roots using genotypes from Bolivia, Ecuador, New Zealand, and Germany reporting a total phenolic content from

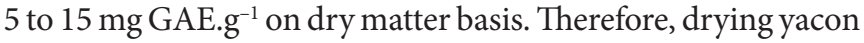
into chips or strips does not significantly affect the phenolic content compared with that in fresh yacon roots.

With regards to yacon chips, the results showed that total phenolic content and the percentage of DPPH inhibited decreased in chips dried at 40 and $60{ }^{\circ} \mathrm{C}$ (Figure 1). The temperatures used for drying in the present study, are in the range at which polyphenol oxidases in yacon roots are active (NEVES; DA SILVA, 2007). Neves and da Silva (2007) found that the optimum temperature of polyphenol oxidases activity in yacon is $30^{\circ} \mathrm{C}$, and their enzymatic activity progressively decreases as the temperature reaches $80^{\circ} \mathrm{C}$. Therefore, when drying at $40^{\circ} \mathrm{C}$, there is a reduction in phenolic content and in the percentage of DPPH inhibited (Figure 1). Similarly, chips dried at $60^{\circ} \mathrm{C}$ had lower phenolic content compared to those dried at $50^{\circ} \mathrm{C}$. An increase in temperature shortens drying time and inactivates polyphenol oxidases to some extent, but it may also cause a loss of thermo sensitive antioxidant compounds during processing (BROOKS; EL-HANA; GHALY, 2008; CHANG et al., 2006; ZANONI et al., 1998). Despite the differences in total phenolic content (TP) and quenching of DPPH in yacon chips, no significant differences were found in the total antioxidant status (TAS) (Figure 1).

To summarise, the antioxidant capacity was less affected when yacon was processed into chips and dried at $50{ }^{\circ} \mathrm{C}$. Negi and Roy (2001) also found lower levels of antioxidant compounds when sun drying was used compared to cabinet drying. The time that the drying process takes can indirectly affect the retention of phenolic compounds. Depending on the geometry of the samples, the drying time can be reduced. This is a reason why to process yacon into chips; increasing surface area per weight results in a faster decrease in moisture content over time (BROOKS; EL-HANA; GHALY, 2008).

Storage time is another factor that can affect retention of antioxidant capacity in dried strips and chips. Strips and chips were packaged in polyethylene bags and stored for 7 months at $20{ }^{\circ} \mathrm{C}$ in a dark and ventilated room.

A difference in total phenolic content was found between freshly dried strips and chips compared with samples stored for 7 months (Figure 2). The percentage of phenolic compounds lost in chips and strips was 31 and 20\%, respectively. Unlike what happens to strips, the decrease of phenolic compounds in chips was significant. A likely explanation for this is the large surface area per mass unit that chips have in comparison to strips. There could be an interaction between the surface of chips and the remaining oxygen inside the polyethylene bag. As a result, a more extensive oxidation of phenolic compounds occurs in comparison to that in strips during storage.

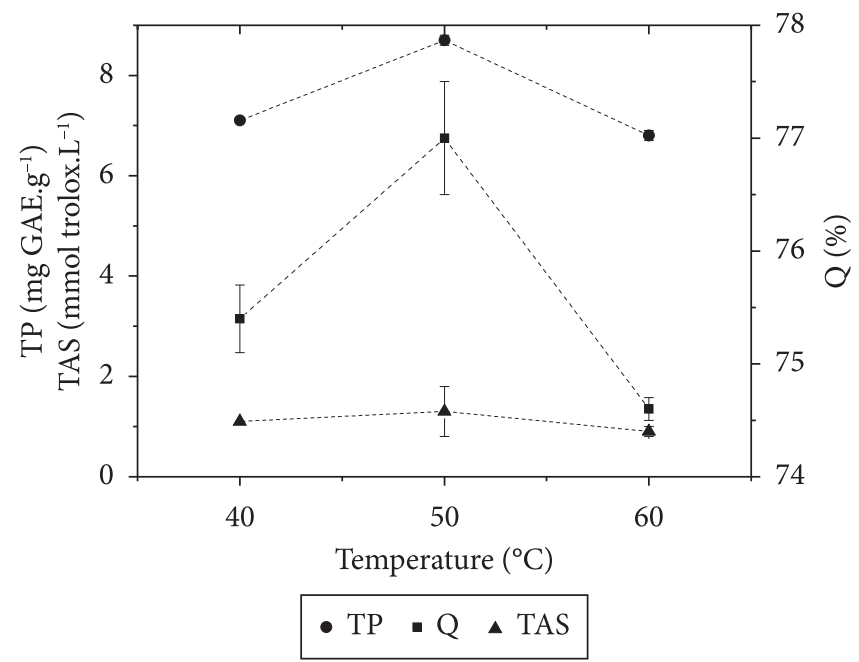

Figure 1. Antioxidant capacity determined as Total Phenol content (TP •), percentage of DPPH inhibited (Q •) and Total Antioxidant Status (TAS $\boldsymbol{\Delta}$ ) in yacon chips at different drying temperatures. Mean values on fresh weight basis and standard error of the mean from two replicates.

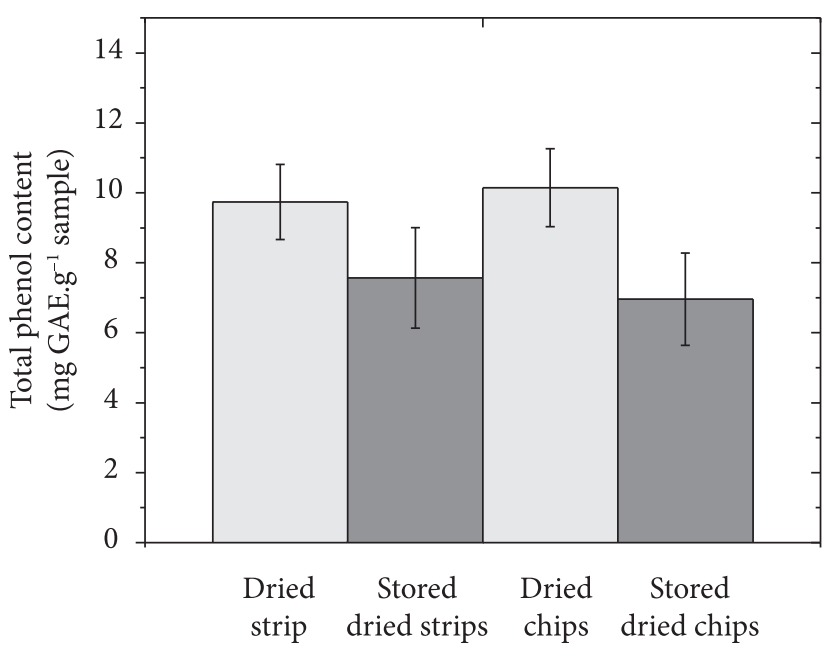

Figure 2. Total phenol content (mg GAE.g- ${ }^{1}$ of sample) determined in dried yacon strips and chips before and after 7 months of storage. Error bars are standard error of the mean.

The time used in processing and/or storage affect the antioxidant level and antioxidant capacity in the product (NEGI; ROY, 2000, 2001; WU et al., 2004). Therefore, it is important and necessary to determine the content of antioxidants in the final product.

\section{Conclusions}

Through drying, it is possible to retain antioxidant capacity in yacon roots. The retention of antioxidant activity depends on the drying method employed and the geometry of the samples. Processing yacon into chips and drying them in a drying cabinet at $50{ }^{\circ} \mathrm{C}$, results in a better retention of antioxidant capacity. 
However, strips have a more suitable shape than that of chips for storage purposes because the larger surface area of chips increases the exposure of phenolic compounds to oxidation by remaining oxygen inside the polyethylene bags. Nevertheless, this can be solved with the use of vacuum packaging.

\section{References}

BROOKS, M. S.; EL-HANA, N. H. A.; GHALY, A. E. Effects of Tomato Geometries and Air Temperature on the Drying Behavior of Plum Tomato. American Journal of Applied Sciences, v. 5, n. 10, p. 1369-1375, 2008. http://dx.doi.org/10.3844/ajassp.2008.1369.1375

CHANG, C. H. et al. Comparisons on the antioxidant properties of fresh, freeze-dried and hot-air-dried tomatoes. Journal of Food Engineering, v. 77, n. 3, p. 478-485, 2006. http://dx.doi. org/10.1016/j.jfoodeng.2005.06.061

GRAU, A.; REA, J. Yacon. Smallanthus sonchifolius (Poepp. \& Endl.) H. Robinson. In: HERMANN, M.; HELLER, J. (Eds.). Andean roots and tubers: Ahipa, arracacha, maca and yacon. Promoting the conservation and use of underutilized and neglected crops. Rome: IPK; Gatersleben: IPGRI, 1997. p. 197-256.

LACHMAN, J. et al. Total phenolic content of yacon (Smallanthus sonchifolius) rhizomes, leaves, and roots affected by genotype. New Zealand Journal of Crop \& Horticultural Science, v. 35, n. 1, p. 117-124, 2007. http://dx.doi.org/10.1080/01140670709510175

MAYER, A. M. Polyphenol oxidases in plants-recent progress. Phytochemistry, v. 26, n. 1, p. 11-20, 1986. http://dx.doi. org/10.1016/S0031-9422(00)81472-7

MOLYNEUX, P. The use of the stable free radical diphenylpicrylhydrazyl (DPPH) for estimating antioxidant. Songklanakarin Journal of Science and Technology, v. 26, n. 2, p. 211-219, 2004.

NEGI, P. S.; ROY, S. K. Effect of low-cost storage and packaging on quality and nutritive value of fresh and dehydrated carrots. Journal of the Science of Food and Agriculture, v. 80, n. 15, p. 2169-2175, 2000. http://dx.doi.org/10.1002/1097-0010(200012)80:15\%3C2169::AIDJSFA762\%3E3.0.CO;2-J

NEGI, P. S.; ROY, S. K. Effect of drying conditions on quality of green leaves during long term storage. Food Research International, v. 34 , n. 4 , p. 283-287, 2001. http://dx.doi.org/10.1016/S09639969(00)00165-4

NEVES, V. A.; DA SILVA, M. A. Polyphenol Oxidase from Yacon Roots (Smallanthus sonchifolius). Journal of Agricultural and Food Chemistry, v. 55, n. 6, p. 2424-2430, 2007. PMid:17316020. http:// dx.doi.org/10.1021/jf063148w

PRIOR, R. L.; WU, X.; SCHAICH, K. Standardized Methods for the Determination of Antioxidant Capacity and Phenolics in Foods and Dietary Supplements. Journal of Agricultural and Food Chemistry, v. 53, n. 10, p. 4290-4302, 2005. PMid:15884874. http:// dx.doi.org/10.1021/jf0502698

QUEIROZ, C. et al. Polyphenol Oxidase: Characteristics and Mechanisms of Browning Control. Food Reviews International, v. 24, n. 4, p. 361-375, 2008. http://dx.doi.org/10.1080/87559120802089332

SEMINARIO, J.; VALDERRAMA, M.; MANRIQUE, I. El yacon: fundamento para el parovechamineto de un recurso promisorio. Lima: Centro Internacional de la papa - CIP, Universidad Nacional de Cajamarca, Agencia Suiza para el Desarrollo y la Cooperaciäon - COSUDE, 2003.

SIMONOVSKA, B. et al. Investigation of phenolic acids in yacon (Smallanthus sonchifolius) leaves and tubers. Journal of Chromatography A, v. 1016, n. 1, p. 89-98, 2003. http://dx.doi. org/10.1016/S0021-9673(03)01183-X

SINGLETON, V. L.; ROSSI, J. A. Colorimetry of total phenolics with phosphomolybdic - phosphotungstic acid reagents. American Journal of Enology and Viticulture, v. 16, n. 3, p. 144-158, 1965.

TAKENAKA, M. et al. Caffeic Acid Derivatives in the Roots of Yacon (Smallanthus sonchifolius). Journal of Agricultural and Food Chemistry, v. 51, n. 3, p. 793-796, 2003. PMid:12537459. http:// dx.doi.org/10.1021/jf020735i

VASCO, C.; RUALES, J.; KAMAL-ELDIN, A. Total phenolic compounds and antioxidant capacities of major fruits from Ecuador. Food Chemistry, v. 111, n. 4, p. 816-823, 2008. http://dx.doi. org/10.1016/j.foodchem.2008.04.054

WU, X. et al. Development of a database for total antioxidant capacity in foods: a preliminary study. Journal of Food Composition and Analysis, v. 17, n. 3-4, p. 407-422, 2004. http://dx.doi.org/10.1016/j. jfca.2004.03.001

YAN, X. et al. Extraction and Identification of Antioxidants in the Roots of Yacon (Smallanthus sonchifolius). Journal of Agricultural and Food Chemistry, v. 47, n. 11, p. 4711-4713, 1999. PMid:10552877. http://dx.doi.org/10.1021/jf981305o

YORUK, R.; MARSHALL, M. R. Physicochemical properties and function of plant polyphenol oxidase: A review. Journal of Food Biochemistry, v. 27, n. 5, p. 361-422, 2003. http://dx.doi. org/10.1111/j.1745-4514.2003.tb00289.x

YOSHIDA, M. et al. Oxygenation of Bisphenol A to Quinones by Polyphenol Oxidase in Vegetables. Journal of Agricultural and Food Chemistry, v. 50, n. 15, p. 4377-4381, 2002. PMid:12105973. http://dx.doi.org/10.1021/jf020206e

ZANONI, B. et al. Oxidative heat damage of tomato halves as affected by drying. Food Research International, v. 31, n. 5, p. 395-401, 1998. http://dx.doi.org/10.1016/S0963-9969(98)00102-1 